\title{
TEORI LINGUISTIK DAN PSIKOLOGI \\ DALAM PEMBELAJARAN BAHASA
}

\author{
Saepudin \\ Dosen IAIN Parepare \\ Email: saepudin@iainpare.ac.id
}

\begin{abstract}
This article discusses several language theories and psychological theories that influence the educator's point of view in teaching languages both mother tongue and second language learners. Among the linguistic theories described are structuralism theories pioneered by Ferdinand de Saussure in Europe; the first figure to do a study of language with scientific principles and codified so that it can be analyzed using systematic and clear methods. Other figures in this genre are Leonardo Bloomfield, Edward Saphier, Charles Hokait and Charles Fries. Second, the transformational generative theory pioneered by Noam Chomsky, who was born in 1928 in Pennsylvania, United States. Psychological theories discussed are the theories of behaviorism, nativism, cognitivism, functional, constructivism, humanism and cybernetics.
\end{abstract}

Keywords: Theory, Linguistics, Psychology

\begin{abstract}
ABSTRAK
Artikel ini membahas bebarapa teori kebahasaaan dan teori kejiwaan yang mempengaruhi sudut pandang pendidik dalam mengajarkan bahasa baik bahasa ibu maupun bahasa kedua peserta didik. Di anatar teori kebahasaan (linguistic theory) yang dijelaskan adalah teori strukturailisme yang dipelopori oleh Ferdinand de Saussure di Eropa; tokoh pertama yang melakukan kajian tentang bahasa dengan prinsip-prinsip ilmiah dan terkodifikasi sehingga dapat dianalisis dengan menggunakan metode yang sistematis dan Jelas. Tokoh lain aliran ini adalah Leonardo Bloomfield, Edward Saphier, Charles Hokait dan Charles Fries. Kedua, teori transformational generative yang dipelopori oleh Noam Chomsky yang lahir tahun 1928 di Pennsylvania, Amerika Serikat. Sedangkan teori kejiwaan yang dibahas adalah teori behaviorisme, nativisme, kognitivisme, fungsional, konstruktivisme, humanism dan sibernetik.
\end{abstract}

Kata Kunci: Teori, Linguistik, Psikologi 


\section{PENDAHULUAN}

Perkembangan pembelajaran bahasa baik bahasa pertama (B1) dan bahasa kedua (B2) tidak terlepas dari perkembangan model, strategi, pendekatan, metode, teknik, dan taktik baik yang khusus untuk pembelajaran bahasa maupun umum yang dapat diadaptasi.

Metode pembelajaran yang khusus atau metode yang lahir dari proses pembelajaran bahasa adalah metode tata bahasa dan terjemah (grammar and translation method), metode langsung (direct method), metode membaca (reading method), metode dengar ucap (audiolingual method), metode guru diam (the silent way), metode respon fisik total (total physical response), metode suggestopedia, metode pembelajaran bahasa berkelompok (language learning community), dan metode komunikatif (communicative language learning).

Adapun model atau metode umum yang dapat diadaptasi dalam pembelajaran bahasa, misalnya model pembelajaran kooperatif, saintifik proses, contextual teaching and learning (CTL), active learning, PAIKEM, blended learning, web based learning, dan lain-lain.

Keberadaan model maupun metode pembelajaran bahasa tersebut tidak terlepas dari pengaruh sudut pandang seseorang dan teori tentang bahasa dan pembelajaran bahasa. Misalnya, metode audilingual yang menekankan pembiasaan melalui teknik repeatation dan drill merupakan bukti dari adanya pengaruh teori pembeljaran yaitu behaviorisme. Maka, pembelajaran bahasa berdasar pada landasan atau teori bahasa (linguistic) dan teori psikologi yang juga menjadi dasar dalam pembelajaran secara umum.

\section{PEMBAHASAN}

\section{Teori Linguistik}

Pembelajaran bahasa tidak terlepas dari apa yang dikemukakan para linguis tentang bahasa. Orang yang beranggapan bahwa bahasa adalah sebagai fenomena yang bisa dipilah menjadi bagian-bagian secara terpisah, akan memberi perhatian lebih besar kepada cara memahami pembagian masing-masing tersebut. Sementara orang yang beranggapan bahwa bahasa adalah terkait dengan budaya dan merupakan alat interaksi sosial, akan menggunakan metodologi pembelajaran yang kental dengan strategi sosiolinguistik dan komunikatif.

\section{Aliran strukturalisme}

Aliran strukturalisme muncul pada abad 19 dan dipelopori oleh Ferdinand de Saussure di Eropa (Jenewa, Swiss) (1857-1913). Dia adalah tokoh pertama yang melakukan kajian tentang bahasa dengan prinsip-prinsip ilmiah dan terkodifikasi 
sehingga dapat dianalisis dengan menggunakan metode yang sistematis dan Jelas. Tokoh lain aliran ini adalah Leonardo Bloomfield, Edward Saphier, Charles Hokait dan Charles Fries.

Pandangan strukturalisme adalah:

a. Pembelajaran bahasa merupakan pemerolehan kebiasaan yang dimantapkan dengan latihan dan penguatan. Bahasa merupakan sebuah keterampilan yang diperoleh dari lingkungan sekitar kemudian dilancarkan melalui metode peniruan dan penguatan.

b. Bahasa adalah segala sesuatu yang diucapkan karena bahasa lisan lebih sempurna dari bahasa tulis.

c. Setiap bahasa memiliki aturan tersendiri yang berbeda dengan bahasa lain.

d. Setiap bahasa mencakup aturan yang saling menyempurnakan sehingga pembicara cukup menyempurnakan apa yang ada dalam pikirannya dengan berpedoman pada aturan bahasa tersebut.

e. Semua bahasa mengalami perubahan dan perkembangan.

f. Standar akhir untuk membenarkan dan menerima bahasa adalah penutur asli bahasa tersebut.

g. Tujuan utama penggunaan bahasa adalah bertukar pikiran dan pendapat serta berkomunikasi.

h. Teknik penelitian yang digunakan dalam bidang ilmu eksakta sama dengan teknik penelitian bahasa.

Prinsip-prinsip yang dikemukakan oleh aliran strukturalisme tentang analisis bahasa mempunyai hubungan erat dengan aliran behaviorisme.

Aliran ini merapkan prinsip-prinsip pembelajaran bahasa sebagai berikut:

a. Pembelajaran bahasa merupakan pemerolehan kebiasaan yang harus dimantapkan dengan pengulangan, latihan, peniruan, dan hafalan.

b. Segala sesuatu yang diucapkan merupakan aspek yang paling penting. Oleh karena itu guru harus memulai pembelajaran dengan memberikan latihan pada siswa dimulai dari latihan menyimak, memahami dan berbicara.

c. Perbedaan antara bahasa asli siswa dengan bahasa target harus mendapat perhatian besar.

d. Guru membedakan konsep bahasa ibu dangan bahasa target melalui terjemahan.

e. Kaidah bahasa itu mengalami perubahan.

f. Kaidah bahasa adalah sebuah deskripsi dari bahasa yang digunakan oleh penuturnya.

g. Penjelasan guru bersipat induktif. 
Kegiatan belajar bahasa menurut teori ini adalah :

a. Guru melatih, menyuruh menirukan dan menghafal bahasa, karena belajar bahasa itu adalah kebiasaan dan latihan.

b. Guru memulai materi dengan melatih siswa dengan keterampilan memdengar, memahami kemudian berbicara, membaca dan menulis.

c. Guru membandingkan bahasa anak didik dan bahasa sasaran.

d. Guru boleh menerjemahkan kata-kata atau kalimat yang dibandingkan.

e. Guru menjelaskan bahwa tata bahasa adalah bukan suatu yang tetap namun dapat berubah seiring dengan perubahan dan perkembangan bahasa.

f. Guru selalu menekankan kepada siswa mengucap, mengeja dan menggunakan ungkapan-ungkapan dengan benar.

\section{Aliran transformational generative}

Aliran ini adalah salah satu aliran linguistik yang berasumsi bahwa pembelajaran bahasa adalah sebuah proses pembentukan kaidah, bukan sebagai pembentukan kebiasaan, seperti yang diyakini oleh aliran strukturalisme dan didukung oleh aliran behaviorisme.

Aliran ini dipelopori oleh Noam Chomsky yang lahir tahun 1928 di Pennsylvania, Amerika Serikat. Dia lahir di tengah keluarga Yahudi radikal keturunan Rusia. Ayahnya, William Chomsky merupakan seorang ahli bahasa Yahudi yang terkenal. Dia adalah seorang profesor linguistik dari Institut Teknologi Massachusetts. Salah satu reputasi Chomsky di bidang linguistik terpahat lewat teorinya tentang tata bahasa generatif.

Pandangan aliran ini:

a. Konsep mengenai deep structure dan surface structure.

b. Gagasan mengenai cara bertolak dari unsur-unsur formatif dalam struktur permukaan menuju struktur dalam melalui sejumlah prosedur di antaranya dengan mengubah suatu struktur ke dalam sruktur lain.

c. Bahasa adalah fitrah "innate", atau potensi dasar yang dimiliki manusia sejak lahir.

d. Manusia memiliki kesiapan fitrah untuk belajar bahasa yang dinamakan alat pemerolehan bahasa (language acquisition device/LAD).

e. Konsep mengenai language competence dan language performance.

f. Dalam proses pemerolehan bahasa terdapat konsep universal sehingga secara mental telah mengetahui kodrat-kodrat yang universal tersebut.

g. Seseorang diyakini mempunyai kemampuan mentransfer "kata sentral" bersama-sama dengan kata-kata lainnya yang bersipat terbuka. 
h. Objek kajian kebahasan berkisar pada kognisi/pengetahuan (language competence) yang dimiliki anak. Kemampuan transformasi satu kalimat menjadi kalimat lain yang pada gilirannya melahirkan performansi bahasa.

\section{Teori Psikologi dalam Pembelajaran Bahasa}

Kemampuan berpikir dan berbahasa merupakan ciri utama yang membedakan manusia dengan makhluk lainnya. Karena memiliki keduanya, maka sering disebut manusia sebagai makhluk yang mulia dan makhluk sosial. Dengan pikirannya manusia menjelajah ke setiap fenomena yang nampak bahkan yang tidak nampak. Dengan bahasanya, manusia berkomunikasi untuk bersosialisasi dan menyampaikan hasil pemikirannya.

Salah satu objek pemikiran manusia adalah bagaimana manusia dapat berbahasa. Pendapat para ahli tentang belajar bahasa tersebut bermacam-macam. Di antara pendapat mereka ada yang bertentangan namun ada juga yang saling mendukung dan melengkapi. Pemikiran para ahli tentang teori belajar bahasa ini begitu variatif dan menarik. Oleh karena itu, kami jadikan salah satu alasan pembahasan dalam bab ini.

Sehubungan dengan begitu banyaknya teori tentang belajar bahasa, maka yang akan dikemukakan dalam bab ini adalah teori Behaviorisme, Nativisme, Kognitivisme, Fungsional, Konstruktivisme, Humanistik, dan Sibernetik. Hal ini dimaksudkan agar pembahasan kami menjadi lebih terfokus.Teori- teori ini ternyata berpengaruh sangat kuat dalam dunia ilmu bahasa. Sebelum kita berbicara lebih jauh tentang teori belajar bahasa, kita pahami dulu pengertian teori. Menurut Mc Lauglin dalam (Hadley: 43, 1993), fungsi teori adalah untuk membantu kita mengerti dan mengorganisasi data tentang pengalaman dan memberikan makna yang merujuk dan sesuai. Ellis menyatakan bahwa setiap guru pasti sudah memiliki teori tentang pembelajaran bahasa, tetapi sebagian besar guru tersebut tidak pernah mengungkapkan seperti apa teori itu. Teori mempunyai fungsi yaitu:

a. Mendeskripsikan, menerangkan, menjelaskan tentang fakta. Contohnya fakta bahwa mengapa air laut itu asin.

b. Meramalkan kejadian-kejadian yang akan terjadi berdasarkan teori yang sudah ada.

c. Mengendalikan yaitu mencegah sesuatu supaya tidak terjadi dan mengusahakan supaya terjadi

Teori berhubungan dengan belajar. Belajar adalah acquiring or getting knowledge of a subject or a skill by study, experience, or instruction (pemerolehan ilmu melalui belajar, pengalaman, pelatihan) atau learning is relatively permanent 
change in a behavioral tendency and is the result of reinforced practice (Kimble and Garmezy, 1963). Dengan kata lain teori belajar bahasa adalah gagasan-gagasan tentang pemerolehan bahasa.

Semua kegiatan belajar melibatkan ingatan. Jika kita tidak dapat mengingat apa pun pengalaman kita maka kita tidak dapat belajar. Seringkali kita lupa, padahal sesuatu yang kita lupakan belum tentu hilang dari ingatan. Refleksi dari pengalaman belajar di sekolah menunjukkan bahwa sesuatu yang pernah dipelajari sungguh-sungguh bisa menjadi lupa. Ingatan dapat digali kembali dengan cara merangsang otak. Pengetahuan yang terlupakan dapat diingat kembali dengan cara belajar kembali.

Menurut Oemar Hamalik ${ }^{1}$, prinsip belajar meliputi:

a. Dilakukan dengan sengaja.

b. Harus direncanakan sebelumnya dengan struktur tertentu.

c. Guru menciptakan pembelajaran bagi siswa.

d. Memberikan hasil tertentu bagi siswa.

e. Hasil-hasil yang dicapai dapat dikontrol dengan cermat.

f. Sistem penilaian dilaksanakan secara berkesinambungan.

Sedangkan ciri-ciri perubahan perilaku dalam belajar: terjadi secara sadar, bersifat kontinu, fungsional, bersifat positif, aktif, tidak bersifat sementara, bertujuan atau terarah, mencakup seluruh aspek perilaku individu. Proses belajar diharapkan membawa perubahan (dalam arti behavioral Changes, aktual maupun potensial), menghasilkan kecakapan baru, adanya usaha mencapai hasil yang lebih baik (dengan sengaja).

Sehubungan dengan prinsip belajar tersebut kiranya teori belajar ini dapat bermanfaat dalam pengembangan pembelajaran bahasa dan dapat menambah wawasan pembaca tentang pemerolehan bahasa.

\section{a. Teori behaviorisme}

Tokoh aliran ini adalah John B. Watson (1878 - 1958) yang di Amerika dikenal sebagai bapak behaviorisme. Teorinya menekankan perhatian pada aspek yang dirasakan secara langsung pada perilaku berbahasa serta hubungan antara stimulus dan respons pada dunia sekelilingnya. Menurut teori ini, semua perilaku, termasuk tindak balas (respons) ditimbulkan oleh adanya rangsangan (stimulus). Jika rangsangan telah diamati dan diketahui maka gerak balas pun dapat diprediksikan. Watson juga dengan tegas menolak pengaruh naluri (instinct) dan

\section{h. 154}

${ }^{1}$ Hamalik, Oemar, Pengembangan Kurikulum, (Cet. I;Bandung: Mandar Maju, 1990), 
kesadaran terhadap perilaku. Jadi setiap perilaku dapat dipelajari menurut hubungan stimulus-respons.

Untuk membuktikan kebenaran teorinya, Watson mengadakan eksperimen terhadap Albert, seorang bayi berumur sebelas bulan. Pada mulanya Albert adalah bayi yang gembira dan tidak takut bahkan senang bermain-main dengan tikus putih berbulu halus. Dalam eksperimennya, Watson memulai proses pembiasaannya dengan cara memukul sebatang besi dengan sebuah palu setiap kali Albert mendekati dan ingin memegang tikus putih itu. Akibatnya, tidak lama kemudian Albert menjadi takut terhadap tikus putih juga kelinci putih. Bahkan terhadap semua benda berbulu putih, termasuk jaket dan topeng sinterklas yang berjanggut putih. Dengan demikian dapat disimpulkan bahwa pembiasaan dapat mengubah perilaku seseorang secara nyata.

Seorang behavioris menganggap bahwa perilaku berbahasa yang efektif merupakan hasil respons tertentu yang dikuatkan. Respons itu akan menjadi kebiasaan atau terkondisikan, baik respons yang berupa pemahaman atau respons yang berwujud ujaran. Seseorang belajar memahami ujaran dengan mereaksi stimulus secara memadai dan memperoleh penguatan untuk reaksi itu.

Salah satu percobaan yang terkenal untuk membentuk model perilaku berbahasa dari sudut behavioris adalah yang dikemukakan oleh Skinner (1957) dalam verbal behavior. Percobaan Skiner dikenal dengan percobaannya tentang perilaku binatang yang terkenal dengan kotak Skinner. Teori Skinner tentang perilaku verbal merupakan perluasan teorinya tentang belajar yang disebutnya operant conditioning. Konsep ini mengacu pada kondisi ketika manusia atau binatang mengirimkan respons atau operant (ujaran atau sebuah kalimat) tanpa adanya stimulus yang tampak. Operant itu dipertahankan dengan penguatan. Misalnya, jika seorang anak kecil mengatakan minta susu dan orang tuanya memberinya susu, maka operant itu dikuatkan. Dengan perulangan yang terus menerus operant semacam itu akan terkondisikan.

Menurut Skinner, perilaku verbal adalah perilaku yang dikendalikan oleh akibatnya. Bila akibatnya itu hadiah, perilaku itu akan terus dipertahankan. Kekuatan serta frekuensinya akan terus dikembangkan. Bila akibatnya hukuman, atau bila kurang adanya penguatan, perilaku itu akan diperlemah atau pelan-pelan akan disingkirkan.

Sebagai contoh dapat kita saksikan perilaku anak-anak di sekeliling kita. Ada anak kecil menangis meminta es pada ibunya. Tetapi, karena ibunya yakin dan percaya bahwa es itu menggunakan pemanis buatan maka sang ibu tidak meluluskan permintaan anaknya. Sang anak terus menangis. Tetapi sang ibu bersikukuh tidak menuruti permintaannya. Lama kelamaan tangis anak tersebut 
akan reda dan lain kali tidak akan minta es semacam itu lagi kepada ibunya, apalagi dengan menangis. Seandainya anak itu kemudian dituruti keinginannya oleh ibunya, apa yang terjadi? Pada kesempatan yang lain sang anak akan minta es lagi. Apabila ibunya tidak meluluskannya maka ia akan menangis dan terus menangis sebab dengan menangis ia akan mendapatkan es. Kalau ibunya memberi es lagi maka perbuatan menangis itu dikuatkan. Pada kesempatan lain dia akan menangis manakala ia meminta sesuatu pada ibunya.

Implikasi teori ini ialah bahwa guru harus berhati-hati dalam menentukan jenis hadiah dan hukuman. Guru harus mengetahui benar kesenangan siswanya. Hukuman harus benar-benar sesuatu yang tidak disukai anak, dan sebaliknya hadiah merupakan hal yang sangat disukai anak. Jangan sampai anak diberi hadiah menganggapnya sebagai hukuman atau sebaliknya, apa yang menurut guru adalah hukuman bagi siswa dianggap sebagai hadiah. Contoh, anak yang suka bermain sepakbola, akan menganggap pemberian waktu untuk bermain sepakbola adalah hadiah, sebaliknya, melarang untuk sementara waktu tidak bermain sepakbola adalah hukuman yang menyakitkan.

Beberapa linguis dan ahli psikologi sependapat bahwa model Skinner tentang perilaku berbahasa dapat diterima secara memadai untuk kapasitas memperoleh bahasa, untuk perkembangan bahasa itu sendiri, untuk hakikat bahasa dan teori makna. Teori yang tak kalah menariknya untuk kita kaji adalah teori pembiasaan klasik dari Pavlov (1848-1936) yang merupakan teori stimulus-respons yang pertama menjadi dasar lahirnya teori-teori stimulus-respons yang lainnya. Pavlov berpendapat bahwa pembelajaran merupakan rangkaian panjang dari responsrespons yang dibiasakan. Menurut teori pembiasaan klasik ini kemampuan seseorang untuk membentuk respons-respons yang dibiasakan berhubungan erat dengan jenis sistem yang digunakan. Teori ini percaya adanya perbedaanperbedaan yang dibawa sejak lahir dalam kemampuan belajar. Respons yang dibiasakan dapat diperkuat dengan ulangan-ulangan teratur dan intensif. Pavlov tidak percaya dengan pengertian atau pemahaman atau apa yang disebut insight (kecepatan melihat hubungan-hubungan di dalam pikiran). Jadi dapat dikatakan bagi Pavlov respons yang dibiasakan adalah unit dasar pembelajaran yang paling baik.

Teori Pavlov tersebut didukung pula oleh Thorndike (1874-1919) yang menghasilkan teori penghubungan atau dikenal dengan trial and error. Teori ini didasarkan pada sebuah eksperimen yang tak jauh berbeda dengan Pavlov. Thorndike menggunakan kucing sebagai sarana eksperimennya yang berhasil membuka engsel dengan cara dibiasakan dan dihubung-gubungkan. Dari hasil eksperimen itu, Thorndike berpendapat bahwa pembelajaran merupakan suatu 
proses menghubung-hubungkan di dalam sistem saraf dan tidak ada hubungannya dengan insight atau pengertian. Yang dihubungkan adalah peristiwa-peristiwa fisik dan mental dalam pembelajaran itu. Yang dimaksud dengan peristiwa fisik adalah segala rangsangan (stimulus) dan gerak balas (respons). Sedangkan peristiwa mental adalah segala hal yang dirasakan oleh pikiran (akal). Thorndike menemukan hukum latihan (the law of exercise) dan hukum akibat (the law of effect) yang kita kenal sekarang dengan reinforcement atau penguatan. Contoh dalam kehidupan sehari-hari adalah ketika belajar naik sepeda atau dalam belajar bahasa adalah dalam pengucapan kata-kata sulit. Kegagalan yang diulang terus menerus lama-kelamaan akan berhasil.

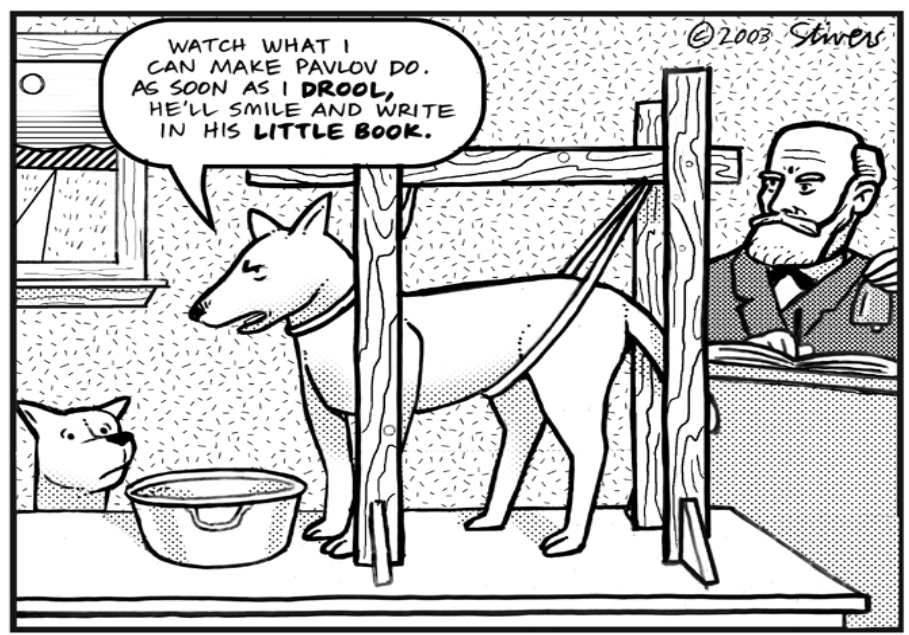

Upaya lain untuk mendukung teori behaviorisme dalam pemerolehan bahasa dilakukan Osgood (1953). Dia menjelaskan bahwa proses pemerolehan semantik (makna) didasarkan pada teori mediasi atau penengah. Menurutnya, makna merupakan hasil proses pembelajaran dan pengalaman seseorang dan merupakan mediasi untuk melambangkan sesuatu. Makna sebagai proses mediasi pelambang dan merupakan satu bagian yang distingtif dari keseluruhan respons terhadap suatu objek yang dibiasakan pada kata untuk objek itu, atau persepsi untuk objek itu. Osgood telah memperkenalkan konsep sign (tanda atau isyarat) sehubungan dengan makna.

Pendapat para ahli psikologi behaviorisme yang menekankan pada observasi empirik dan metode ilmiah hanya dapat menjelaskan keajaiban pemerolehan dan belajar bahasa tapi ranah kajian bahasa yang sangat luas masih tetap tak tersentuh. 


\section{b. Teori nativisme}

Berbeda dengan kaum behavioristik, kaum nativistik atau mentalistik berpendapat bahwa pemerolehan bahasa pada manusia tidak boleh disamakan dengan proses pengenalan yang terjadi pada hewan. Mereka tidak memandang penting pengaruh dari lingkungan sekitar. Selama belajar bahasa pertama sedikit demi sedikit manusia akan membuka kemampuan lingualnya yang secara genetis telah terprogramkan. Dengan perkataan lain, mereka menganggap bahwa bahasa merupakan pemberian biologis. Menurut mereka bahasa terlalu kompleks dan mustahil dapat dipelajari oleh manusia dalam waktu yang relatif singkat lewat proses peniruan sebagaimana keyakinan kaum behavioristik. Jadi beberapa aspek penting yang menyangkut sistem bahasa menurut keyakinan mereka pasti sudah ada dalam diri setiap manusia secara alamiah.

Istilah nativisme dihasilkan dari pernyataan mendasar bahwa pembelajaran bahasa ditentukan oleh bakat. Bahwa setiap manusia dilahirkan sudah memiliki bakat untuk memperoleh dan belajar bahasa. Teori tentang bakat bahasa itu memperoleh dukungan dari berbagai sisi. Eric Lenneberg (1967) membuat proposisi bahwa bahasa itu merupakan perilaku khusus manusia dan bahwa cara pemahaman tertentu, pengkategorian kemampuan, dan mekanisme bahasa yang lain yang berhubungan ditentukan secara biologis.

Chomsky yang merupakan tokoh utama golongan ini mengatakan bahwasannya hanya manusialah satu-satunya makhluk Tuhan yang dapat melakukan komunikasi lewat bahasa verbal. Selain itu bahasa juga sangat kompleks oleh sebab itu tidak mungkin manusia belajar bahasa dari makhluk Tuhan yang lain. Chomsky juga menyatakan bahwa setiap anak yang lahir ke dunia telah memiliki bekal dengan apa yang disebutnya "alat penguasaan bahasa" atau LAD (language Acquisition Device). Dia mengemukakan bahwa belajar bahasa merupakan kompetensi khusus bukan sekedar subset belajar secara umum. Cara berbahasa jauh lebih rumit dari sekedar penetapan stimulus-respon. Selain itu, dia mengatakan bahwa eksistensi bakat bermanfaat untuk menjelaskan rahasia penguasaan bahasa pertama anak dalam waktu singkat, karena adanya LAD. Menurut golongan ini belajar bahasa pada hakikatnya hanyalah proses pengisian kaidah-kaidah atau struktur aturan-aturan bahasa ke dalam LAD yang sudah tersedia secara alamiah pada manusia tersebut.

LAD itu terdiri atas empat bakat bahasa, yakni:

1) Kemampuan untuk membedakan bunyi bahasa dengan bunyi-bunyi yang lain;

2) Kemampuan mengorganisasikan peristiwa bahasa ke dalam variasi yang beragam; 
3) Pengetahuan adanya sistem bahasa tertentu yang mungkin dan sistem yang lain yang tidak mungkin;

4) Kemampuan untuk mengevaluasi sistem perkembangan bahasa yang membentuk sistem yang mungkin dengan cara yang paling sederhana dari data kebahasaan yang diperoleh. Manusia mempunyai bakat untuk terus menerus mengevaluasi sistem bahasanya dan terus menerus mengadakan revisi untuk pada akhirnya menuju bentuk yang berterima di lingkungannya.

Chomsky mengemukakan bahwa bahasa anak adalah sistem yang sah dari sistem mereka. Perkembangan bahasa anak bukanlah proses perkembangan sedikit demi sedikit stuktur yang salah, bukan dari bahasa tahap pertama yang lebih banyak salahnya ke tahap berikutnya, tetapi bahasa anak pada setiap tahapan itu sistematik dalam arti anak secara terus menerus membentuk hipotesis dengan dasar masukan yang diterimanya dan kemudian mengujinya dalam ujarannya sendiri dan pemahamannya. Selama bahasa anak itu berkembang hipotesis itu terus direvisi, dibentuk lagi atau kadang-kadang dipertahankan.

\section{c. Teori kognitivisme}

Pada tahun 60-an golongan kognitivistik mencoba mengusulkan pendekatan baru dalam studi pemerolehan bahasa. Pendekatan tersebut mereka namakan pendekatan kognitif. Jika pendekatan kaum behavioristik bersifat empiris maka pendekatan yang dianut golongan kognitivistik lebih bersifat rasionalis. Konsep sentral dari pendekatan ini yakni kemampuan berbahasa seseorang berasal dan diperoleh sebagai akibat dari kematangan kognitif sang anak. Mereka beranggapan bahwa bahasa itu distrukturkan atau dikendalikan oleh nalar manusia. Oleh sebab itu perkembangan bahasa harus berlandas pada atau diturunkan dari perkembangan dan perubahan yang lebih mendasar dan lebih umum di dalam kognisi manusia. Dengan demikian urutan-urutan perkembangan kognisi seorang anak akan menentukan urutan-urutan perkembangan bahasa dirinya.

Menurut aliran ini kita belajar disebabkan oleh kemampuan kita menafsirkan peristiwa atau kejadian yang terjadi di dalam lingkungan. Titik awal teori kognitif adalah anggapan terhadap kapasitas kognitif anak dalam menemukan struktur dalam bahasa yang didengar di sekelilingnya. Pemahaman, produksi, komprehensi bahasa pada anak dipandang sebagai hasil dari proses kognitif anak yang secara terus menerus berubah dan berkembang. Jadi stimulus merupakan masukan bagi anak yang berproses dalam otak. Pada otak terjadi mekanisme mental internal yang 
diatur oleh pengatur kognitif, kemudian keluar sebagai hasil pengolahan kognitif tadi.

Konsep sentral teori kognitif adalah kemampuan berbahasa anak berasal dari kematangan kognitifnya. Proses belajar bahasa secara kognitif merupakan proses berpikir yang kompleks karena menyangkut lapisan bahasa yang terdalam. Lapisan bahasa tersebut meliputi: ingatan, persepsi, pikiran, makna, dan emosi yang saling berpengaruh pada struktur jiwa manusia. Bahasa dipandang sebagai manifestasi dari perkembangan aspek kognitif dan afektif yang menyatakan tentang dunia dan diri manusia itu sendiri.

Dapat dikemukakan bahwa pendekatan kognitif menjelaskan bahwa:

1) Dalam belajar bahasa, bagaimana kita berpikir;

2) Belajar terjadi dan kegiatan mental internal dalam diri kita;

3) Belajar bahasa merupakan proses berpikir yang kompleks.

Dalam belajar bahasa seorang anak perlu proses pengendalian dalam berinteraksi dengan lingkungan. Pendekatan kognitif dalam belajar bahasa lebih menekankan pemahaman, proses mental atau pengaturan dalam pemerolehan, dan memandang anak sebagai seseorang yang berperan aktif dalam proses belajar bahasa.

Selanjutnya menurut Piaget, salah seorang tokoh golongan ini mengatakan bahwa struktur komplek dari bahasa bukanlah sesuatu yang diberikan oleh alam dan bukan pula sesuatu yang dipelajari lewat lingkungan. Struktur tersebut lahir dan berkembang sebagai akibat interaksi yang terus menerus antara tingkat fungsi kognitif si anak dan lingkungan lingualnya. Struktur tersebut telah tersedia secara alamiah. Perubahan atau perkembangan bahasa pada anak akan bergantung pada sejauh mana keterlibatan kognitif sang anak secara aktif dengan lingkungannya.

Proses belajar bahasa terjadi menurut pola tahapan perkembangan tertentu sesuai umur. Tahapan tersebut meliputi:

1) Asimilasi: proses penyesuaian pengetahuan baru dengan struktur kognitif

2) Akomodasi: proses penyesuaian struktur kognitif dengan pengetahuan baru

3) Disquilibrasi: proses penerimaan pengetahuan baru yang tidak sama dengan yang telah diketahuinya.

4) Equilibrasi: proses penyeimbang mental setelah terjadi proses asimilasi.

Berdasarkan pola tahapan perkembangan di atas dapat dikatakan bahwa proses belajar bahasa terjadi bila anak mampu mengasimilasikan pengetahuan yang dimiliki dengan pengetahuan baru. Proses itu melalui tahapan memperhatikan stimulus yang diberikan, memahami makna stimulus, menyimpan dan menggunakan informasi yang sudah dipahami. 
Proses belajar bahasa lebih ditentukan oleh cara anak mengatur materi bahasa bukan usia anak. Proses belajar bahasa didapat melalui enaktif yaitu aktivitas untuk memahami lingkungan; ikonik yaitu melihat dunia lewat gambar dan visualisasi verbal dan simbolik yaitu memahami gagasan-gagasan abstrak.

\section{d. Teori fungsional}

Dengan munculnya kontruktivisme dalam dunia psikologi, dalam tahun-tahun terakhir ini menjadi lebih jelas bahwa belajar bahasa berkembang dengan baik di bawah gagasan kognitif dan struktur ingatan.

Para peneliti bahasa mulai melihat bahwa bahasa merupakan manifestasi kemampuan kognitif dan efektif untuk menjelajah dunia, untuk berhubungan dengan orang lain dan juga keperluan terhadap diri sendiri sebagai manusia. Lebih lagi kaedah generatif yang diusulkan di bawah naungan nativisme itu bersifat abstrak, formal, eksplisit dan logis, meskipun kaidah itu lebih mengutamakan pada bentuk bahasa dan tidak pada tataran fungsional yang lebih dari makna yang dibentuk dari interaksi sosial.

1) Kognisi dan perkembangan bahasa

Piaget menggambarkan penelitian itu sebagai interaksi anak dengan lingkungannya dengan interaksi komplementer antara perkembangan kapasitas kognitif perseptual dengan pengalaman bahasa mereka. Penelitian itu berkaitan dengan hubungan antara perkembangan kognitif dengan pemerolehan bahasa pertama. Slobin menyatakan bahwa dalam semua bahasa, belajar makna bergantung pada perkembangan kognitif dan urutan perkembangannya lebih ditentukan oleh kompleksitas makna itu dari pada kompleksitas bentuknya. Menurut dia ada dua hal yang menentukan model:

a) Pada asas fungsional, perkembangan diikuti oleh perkembangan kapasitas komunikatif dan konseptual yang beroperasi dalam konjungsi dengan skema batin konjungsi.

b) Pada asas formal, perkembangan diikuti oleh kapasitas perseptual dan pemerosesan informasi yang bekerja dalam konjungsi dan skema batin tata bahasa.

2) Interaksi sosial dan perkembangan bahasa

Akhir-akhir ini semakin jelas bahwa fungsi bahasa berkembang dengan baik di luar pikiran kognitif dan struktur memori. Di sini tampak bahwa kontruktivis sosial menekankan prespektif fungsional. Bahasa pada hakikatnya digunakan untuk komunikasi interaktif. Oleh sebab itu kajian yang cocok untuk itu adalah kajian 
tentang fungsi komunikatif bahasa, fungsi pragmatik dan komunikatif dikaji dengan segala variabilitasnya.

\section{e. Teori konstruktvisme}

Jean Piaget dan Leu Vygotski adalah dua nama yang selalu diasosiasikan dengan kontruktivisme. Ahli kontruktivisme menyatakan bahwa manusia membentuk versi mereka sendiri terhadap kenyataan, mereka menggandakan beragam cara untuk mengetahui dan menggambarkan sesuatu untuk mempelajari pemerolehan bahasa pertama dan kedua.

Pembelajaran harus dibangun secara aktif oleh pembelajar itu sendiri dari pada dijelaskan secara rinci oleh orang lain. Dengan demikian pengetahuan yang diperoleh didapatkan dari pengalaman. Namun demikian, dalam membangun pengalaman siswa harus memiliki kesempatan untuk mengungkapkan pikirannya, menguji ide-ide tersebut melalui eksperimen dan percakapan atau tanya jawab, serta untuk mengamati dan membandingkan fenomena yang sedang diujikan dengan aspek lain dalam kehidupan mereka. Selain itu juga guru memainkan peranan penting dalam mendorong siswa untuk memperhatikan seluruh proses pembelajaran serta menawarkan berbagai cara eksplorasi dan pendekatan.

Siswa dapat benar-benar memahami konsep ilmiah dan sains karena telah mengalaminya. Penjelasan mendetail dari guru belum tentu mencerminkan pemahaman siswa mengerti kata-kata ilmiahnya, tapi tidak memahami konsepnya. Namun jika siswa telah mencobanya sendiri, maka pemahaman yang didapat tidak hanya berupa kata-kata saja, namun berupa konsep.

Dalam rangka kerjanya, ahli konstruktif menantang guru-guru untuk menciptakan lingkungan yang inovatif dengan melibatkan guru dan pelajar untuk memikirkan dan mengoreksi pembelajaran. Untuk itu ada dua hal yang harus dipenuhi, yaitu:

1) Peserta didik harus berperan aktif dalam menyeleksi dan menetapkan kegiatan sehingga menarik dan memotivasi pelajar.

2) Harus ada guru yang tepat untuk membantu peserta didik membuat konsep-konsep, nilai-nilai, skema, dan kemampuan memecahkan masalah.

\section{f. Teori humanisme}

Teori ini muncul diilhami oleh perkembangan dalam psikologi yaitu psikologi humanisme. Sesuai pendapat yang dikemukakan oleh McNeil (1977) "In many instances, communicative language programmes have incorporated educational phylosophies based on humanistic psikology or view which in the context of goals for other subject areas has been called 'the humanistic curriculum'." Teori 
humanisme dalam pengajaran bahasa pernah diimplementasikan dalam sebuah kurikulum pengajaran bahasa dengan istilah humanistic curriculum yang diterapkan di Amerika utara di akhir tahun 1960-an dan awal tahun 1970-an. Kurikulum ini menekankan pada pembagian pengawasan dan tanggungjawab bersama antar seluruh siswa didik. Humanistic curiculum menekankan pada pola pikir, perasaan dan tingkah laku siswa dengan menghubungkan materi yang diajarkan pada kebutuhan dasar dan kebutuhan hidup siswa. Teori ini menganggap bahwa setiap peserta didik sebagai objek pembelajaran memiliki alasan yang berbeda dalam mempelajari bahasa.

Tujuan utama dari teori ini adalah untuk meningkatkan kemampuan siswa agar bisa berkembang di tengah masyarakat. The deepest goal or purpose is to develop the whole persons within a human society. (McNeil,1977)

Sementara tujuan teori humanisme menurut Coombs (1981):

1) Pengajaran disusun berdasarkan kebutuhan-kebutuhan dan tujuan siswa. program pengajaran diarahkan agar siswa mampu menciptakan pengalaman sendiri berdasarkan kebutuhannya. Hal ini dilakukan untuk mengembangkan potensi yang mereka miliki.

2) Memberi kesempatan kepada siswa untuk mengaktualisasikan dirinya dan untuk menumbuhkan kepercayaan dirinya.

3) Pengajaran disusun untuk memperoleh keterampilan dasar (akademik, pribadi, antar pribadi, komunikasi, dan ekonomi) berdasarkan kebutuhan masing-masing siswa.

4) Memilih dan memutuskan aktivitas pengajaran secara individual dan mampu menerapkannya.

5) Mengenal pentingnya perasaan manusia, nilai, dan persepsi.

6) Mengembangkan suasana belajar yang menantang dan bisa dimengerti.

7) Mengembangkan tanggung jawab siswa, mengembangkan sikap tulus, respek, dan menghargai orang lain, dan terampil dalam menyelesaikan konflik.

Teori humanisme dalam pangajaran bahasa banyak dipengaruhi oleh pemikiran para ahli psikologi humanisme seperti Abraham Maslow, Carl Roger, Fritz Peers dan Erich Berne. Para ahli psikologi tersebut menciptakan sebuah teori di mana pendidikan berpusat pada siswa (learner centered-pedagogy). Prakteknya dalam dunia pendidikan yaitu dengan menggabungkan pengembangan kognitif dan afektif siswa.

Dalam teori humanisme, setiap siswa memiliki tanggung jawab terhadap pembelajaran mereka masing-masing, mampu mengambil keputusan sendiri, 
memilih dan mengusulkan aktivitas yang akan dilakukan, mengungkapkan perasaan dan pendapat mengenai kebutuhan, kemampuan, dan kesenangannya. Dalam hal ini, guru berperan sebagai fasilitator pengajaran, bukan menyampaikan pengetahuan.

Pembelajaran bahasa menurut teori humanisme, sebagai berikut:

1) Teori ini sangat menekankan kepada komunikasi yang bermakna (meaningful communication) berdasarkan sudut pandang siswa. Teks harus otentik, tugas-tugas harus komunikatif, Outcome menyesuaikan dan tidak ditentukan atau ditargetkan sebelumnya.

2) Pendekatan ini berfokus pada siswa dengan menghargai existensi setiap individu.

3) Pembelajaran digambarkan sebagai sebuah penerapan pengalaman individual dimana siswa memiliki kesempatan berbicara dalam proses pengambilan keputusan.

4) Siswa lain sebagai kelompok suporter dimana mereka saling berinteraksi, saling membantu dan saling mengevaluasi satu sama lain.

5) Guru berperan sebagai fasilitator yang lebih memperhatikan atmosphere kelas dibanding silabus materi yang digunakan.

6) Materi berdasarkan kebutuhan-kebutuhan siswa.

7) Bahasa ibu para siswa dianggap sebagai alat yang sangat membantu jika diperlukan untuk memahami dan merumuskan hipotesa bahasa yang dipelajari.

Carl Rogers (1902-1987) dianggap sebagai penemu dan panutan dalam perkembangan pendekatan humanistik dalam pendidikan. Roger (1980) menekankan pada kebutuhan secara alamiah dari setiap orang untuk belajar. Peran guru adalah sebagai fasilitator pengajaran.

\section{g. Teori sibernetik}

Istilah sibernetika berasal dari bahasa Yunani (cybernetics berarti pilot). Istilah cybernetics yang diterjemahkan kedalam bahasa Indonesia menjadi sibernetika, pertama kali digunakan tahun 1945 oleh Nobert Wiener dalam bukunya yang berjudul Cybernetics. Nobert mendefinisikan cybernetics sebagai berikut," The study of control and communication in the animal and the machine." Istilah sibernetika digunakan juga oleh Alan Scrivener (2002) dalam bukunya 'A Curriculum for Cybernetics and Systems Theory.' Sebagai berikut "Study of systems which can be mapped using loops (or more complicated looping structures) in the network defining the flow of information. Systems of automatic control will of 
necessity use at least one loop of information flow providing feedback." Artinya studi mengenai sistem yang bisa dipetakan menggunakan loops (berbagai putaran) atau susunan sistem putaran yang rumit dalam jaringan yang menjelaskan arus informasi. Sistem pengontrol secara otomatis akan bermanfaat, satu putaran informasi minimal akan menghasilkan feedback. Sementara Ludwig Bertalanffy memandang fungsi sibernetik dalam berkomunikasi. "Cybernetics is a theory of control systems based on communication (transfer of information) between systems and environment and within the system, and control (feedback) of the system's function in regard to environment.

Sibernetika adalah teori sistem pengontrol yang didasarkan pada komunikasi (penyampaian informasi) antara sistem dan lingkungan dan antar sistem, pengontrol (feedback) dari sistem berfungsi dengan memperhatikan lingkungan.

Seiring perkembangan teknologi informasi yang diluncurkan oleh para ilmuwan dari Amerika sejak tahun 1966, penggunaan komputer sebagai media untuk menyampaikan informasi berkembang pesat. Teknologi ini juga dimanfaatkan dunia pendidikan terutama guru untuk berkomunikasi sesama relasi, mencari handout (buku materi ajar), menerangkan materi pelajaran atau pelatihan, bahkan untuk mengevaluasi hasil belajar siswa. Prinsip dasar teori sibernetik yaitu menghargai adanya 'perbedaan', bahwa suatu hal akan memiliki perbedaan dengan yang lainnya, atau bahwa sesuatu akan berubah seiring perkembangan waktu. Pembelajaran digambarkan sebagai : INPUT $=$ PROSES $=$ P OUTPUT

Teori sibernetik diimplementasikan dalam beberapa pendekatan pengajaran (teaching approach) dan metode pembelajaran, yang sudah banyak diterapkan di Indonesia. Misalnya virtual learning, e-learning, dan lain-lain.

Beberapa kelebihan teori sibernetik:

1) Setiap orang bisa memilih model pembelajaran yang paling sesuai dengan untuk dirinya, dengan mengakses melalui internet pembelajaran serta modulnya dari berbagai penjuru dunia.

2) Pembelajaran bisa disajikan dengan menarik, interaktif dan komunikatif. Dengan animasi-animasi multimedia dan interferensi audio, siswa tidak akan bosan duduk berjam-jam mempelajari modul yang disajikan.

3) Menganggap dunia sebagai sebuah 'global village', dimana masyarakatnya bisa saling mengenal satu sama lain, bisa saling berkomunikai dengan mudah, dan pembelajaran bisa dilakukan di mana saja tanpa dibatasi ruang dan waktu, sepanjang sarana pembelajaran mendukung.

4) Buku-buku materi ajar atau sumber pembelajaran lainnya bisa diperoleh secara autentik (sesuai aslinya), cepat dan murah. 
5) Ketika bertanya atau merespon pertanyaan guru atau instruktur, secara psikologis siswa akan lebih berani mengungkapkanya, karena siswa tidak akan merasa takut salah dan menanggung akibat dari kesalahannya secara langsung.

\section{KESIMPULAN}

Berdasarkan uraian di atas, dapat disimpulkan bahwa dalam proses belajar bahasa dapat ditinjau dari berbagai teori yang kesemuanya masuk akal. Yang terpenting bagi guru dengan adanya teori-teori tersebut dapat membantu kesulitan dakam belajar bahasa sehingga dapat memaksimalkan kemampuan peserta didik.

\section{DAFTAR PUSTAKA}

Brown, Douglas, H. Teaching By Principles: An Interactive Approach to Language Pedagogy. Second Edition, New York: Sun Fransisco State University, 2001.

Brumfit, C.J., dan K. Johnson., 1984. The Communicative Approach to Langauge Teaching. Oxford: Oxford University Press.

Clark, H. Herbert and Eve V. Clark. Psychology and Language. New York: Harcout Brace, 1977.

Cook, Vivian. Second Language Learning and Language Teaching. New York: Chapman and Hall, 1991.

Gazali, A. Syukur. Pembelajaran Keterampilan Berbahasa dengan Pendekatan Komunikatif Integratif. Cet. 1; Bandung: PT Refika Aditama, 2010.

Grabe, William \& Kaplan, B., Robert. Introduction to Applied Linguistics. New York: Addison-Wesley Publishing Company, 1992.

Hamalik, Oemar, Pengembangan Kurikulum, Cet. I;Bandung: Mandar Maju, 1990.

Harmer, Jeremy. The Practice of English Language Teaching. New Edition, UK: Longman, 1991.

Heaton, J. B. Writing English Language Test. New York: Longman, 1991.

Jognson, Elaine B. Contextual Teaching and Learning. California: Corwin Press.

Diterjemahkan Oleh: Ibnu Setiawan. 2007. Dengan judul: Contextual Teaching and Learning: Menjadikan Kegiatan Belajar Mengajar Mengasikan dan Bermakna. Cet. 5; Bandung: MLC.

Johnson, David W, et. al. Colaborative Learning: Strategi Pembelajaran untuk Sukses Bersama. Diterjemahkan oleh: Narulita Yusron. Cet. 1; Bandung: Nusa Media, 2010. 
Johnson, Keith. An Introduction to Foreign Language Learning and Teaching. England: Person Education Limited, 2001.

Mujies, Daniel, dan David Reybolds. Effective Teaching: Evidance adan Practice. London: Sage Publications Ltd. Diterjemahlan oleh: Soetjipto, Helly Prajitno dan Sri Mulyantini Soetjipto. 2008. Efective Teaching: Teori dan aplikasi. Cet. 1; Yogyakarta: Pustaka Pelajar, 2008.

O'Malley, J. Michael and Anna Uhl Chamot. Learning Strategies in Second Language Acquisition. New York: Cambridge University Press, 1990.

Richard, C., Jack \& Theodore S. Rodger. Approaches and Metods in Language Teaching. Unied Kingdom: Cambridge University Press, 2001.

Savignon, J. Sandra. Communicative Competence: Theory and Classroom Practice.: Texts and Contexts in Second Language Learning. London: addison-Wesley Publishing Company, 1983.

Schachter, Jacquelyn. And Susan Gass. Second Language Classroom Research Issues and Opportunities. New Jersey: Lawrence Erlbaum Associates Publisher, 1996.

Sibermen, Melvin, L. Active Learning. 101 Startegies to Teach Any Subject. Massachusetts: Allyn Bacon, 1996. Diterjemahkan Oleh: Sarjuli. Dkk. Active Learning: 101 Strategi Pembelajaran Aktif. Cet. 2; Yogyakarta: Yappendis, 2002. 